\title{
Cooperation at the Institutional and Bilateral Level of the European Union and Central Asia
}

Central Asia is defined as physical-geographic area as well as a hill and mountain region. The main area of it is occupied by the Mongolian Plateau, the Gobi Desert, the Altai Mountains, the Sayan Mountains, Changar, the Khangai Mountains as well as Dzungarian Basin (Mydel, Grocha, 2000, p. 116). The mentioned definition which is based on geographical considerations, does not reflect the geopolitical nature of this region. Primarily, it should be underlined that the title area is inhabited by highly heterogeneous nations that speak numerous languages of distinct language groups and are also mostly characterized by clearly defined cultural and religious distinctness. The term of Central Asia has been distinguished as a synonymous word of High Asia (fr. la Haute Tartarie, l'Asie interieure), used in European literature that concerns geographical and historical issues. It should be mentioned that the term of Central Asia has not been corresponding to the geographical boundaries of the region as far as political background is concerned.

The first person who decided to be more specific in terms of the Central Asia area was a German Geographer - A. von Humboldt, who placed this region 5 degrees north and 5 degrees south lying south of latitude 44,5 in his elaboration published in 1843 . Numerous researchers have been redefining the boundaries of this region in later years, however the Humboldt's definition remained mostly unchanged. The current definition of UNESCO under UN which was developed in 1978 within the final report of the Paris meeting, defines Central Asia as "territory designated by the boundaries of Afghanistan, west part of China, north India, north-eastern Iran, Mongolia, Pakistan and Asian USSR republic" (Dani, Masson, 1992, pp. 467-468).

As a result of the collapse of the Soviet Union in 1991 the place of Soviet republics has been replaced by five novel countries, including: Kazakhstan, Kyrgyzstan, Turkmenistan, Tajikistan and Uzbekistan, while the remaining area of Asian USSR was possessed by Russia. As far as political aspects are concerned, Central Asia is not only a conglomerate of culturally varied countries and nations, but also a place of increasingly strong impact of United States and European Union countries.

Unfortunately, the European Union engagement with reference to the described region is observably smaller than it could be expected taking the actual political and economic significance of Central Asia in the world into consideration. Lack of coherent strategy for Central Asia, especially lack of foreign policy based on transparent foundations, and last but not least, focusing on both strengthening position in Europe as well as on political and economic expansion in Sub-Saharan Africa are considered as the most significant results of this phenomenon (Bello, 2010). 
From worldwide economic processes point of view, Central Asia had been playing a marginal role until quite recently. The changes in terms of this situation were observable after the collapse of the Soviet Union. It was also caused by the China's stronger economic expansion. The rather balanced soviet status quo that lasted since the end of the Second World War had been suddenly disturbed - USSR disappeared and unprecedented dynamics of Chinese economic development resulted in United States activation within the described region. Undoubtedly, the events of September 2001 turned out to be the crucial point concerning political situation in Central Asia, due to the fact that those provoked Washington to take military steps in Afghanistan.

The collapse of Soviet Union had contributed to a noticeable weakening of Russian impacts all over the region. At the same time, the political and economic weakness of the republics emerged on the ruins of the Soviet Union made separation from Russian dependence difficult and even impossible. The situation in the region started to change to the detriment of Moscow along with the economic expansion of China. While Russian aspirations noticeably underlined the aspirations to build the political dependence on the basis of economical help, Pekin implemented its concept of building economic links without basing on the political dependence of partners.

Until finding rich deposits of oil and gas on the territories of former Soviet republics, Moscow was reinforcing its basically exclusive authority in the mentioned area. Furthermore, Kremlin, as a significant supplier of energy raw materials to China, was able to maintain a position of an equivalent partner for China. The development of energy relationship between China and republics with reference to Russia meant not only the weakening of its bargain position towards Pekin, but also revenue losses all over Central Asia. This situation provided Russia with two various procedures, including enhancement of the economic cooperation with Europe and development of the energy networks towards Eastern and South Asia (Olędzki, 2014, pp. 29-54).

The collapse of Soviet Union had resulted also in one more significant from the worldwide political balance point of view event: United States had become the only worldwide political and economic superpower. This situation could not last long and quite quickly the American worldwide autocracy had come to an end. Undoubtedly, as far as economic background is concerned, it was caused by the crisis of 2008 which is recognized as a symbolic date of American economic model bankruptcy. From political point of view, unsuccessful interventions in both Iraq and Afghanistan are considered as the main reason of the weakening of American reputation.

At the background of boiling political-economic mixture in Central Asia, the operation of the second worldwide political-economic superpower - European Union is basically marginal. Generally, it is difficult to make a reference to economic relation of European Union with the region, due to the fact that it is constituted of numerous bilateral political-economic relations of particular Member States. However, it does not mean that Brussels does not consider more active participation in political and economic processes in Central Asia as necessary, with a special attention paid to contracting negative social and environmental results of economic development in the region.

The main aim of the present article is to examine the current state of the cooperation (on both institutional and bilateral level) between European Union and Central Asia countries. The hypothesis of the author is as follows: European Union on both 
institutional level and with regard to the actions of particular Member States, does not show interest in terms of development and enhancement of cooperation with Central Asia countries - it refers to both trade and potential diversification of the sources of obtaining energy raw materials.

\section{Central Asia with regard to European Union policy}

Central Asia is not a homogenous region in terms of political or economic background. Furthermore, despite the fact that the Parliament considers Mongolia as a part of this region, this country is distinct in numerous aspects, due to its history, geographic as well as political aspects. Each country of Central Asia are multidimensional in terms of foreign policy and perform balancing act between Russia, China and West. The everlasting neutrality of Turkmenistan was even approved by UN. Except Kazakhstan and Turkmenistan, all countries included in the region are observed to have their trade relations with European Union highly restricted. Kazakhstan is a founder of customs union with Russia and Belarus. On May 2014 those countries signed the formation of Eurasian Economic Union (together with Armenia) which entered into force on 1 September 2015. Kyrgyzstan joined them on May 2015 (Garces de los Fayos, 2018, pp. 1-3).

It should be mentioned that there are certain legal bases of the cooperation between European Union and Central Asia (Garces de los Fayos, 2018, pp. 1-3):

- $5^{\text {th }}$ Title of the Treaty on European Union (TEU) "external actions";

- Articles 206-207 (trade) and articles 216-219 (international agreements) of the Treaty on the Functioning of the European Union (TFEU);

- Agreements regarding partnership and cooperation concerning mutual relations, except Turkmenistan with which the temporary trade agreement was signed. The agreements regarding partnership and cooperation with Mongolia as well as novel reinforced agreement regarding partnership and cooperation with Kazakhstan are currently ratified by the parliaments of the European Union Member States, awaiting the Parliament's approval.

European Union signed novel reinforced agreement regarding partnership and cooperation with Kazakhstan on December 2015. It awaits ratification, however it has been temporary implemented since 1 May 2016. The agreement regarding partnership and cooperation with Turkmenistan of 1998 may be soon approved by the European Parliament, on condition that a system of control of advances regarding human rights will be simultaneously created. Mongolia signed the agreement regarding partnership and cooperation on May 2013 and its ratification by all of the Member States will be finished in 2017 (Garces de los Fayos, 2018, pp. 1-3).

In 2012 and 2015, as well as on June 2017, the European Union strategy towards Central Asia of 2007 was overviewed. This strategy concerns the basic guidelines for forthcoming interactions in the region and is based on previous European Union agreements, support programme and similar initiatives. Its aim is to achieve a sustainability and prosperity, while promoting an open-minded society, legality, democratization and closer cooperation in terms of energy security and diversification on energy sources 
at the same time. In the future, the hydrocarbon resources of both Kazakhstan and Turkmenistan are forecasted to be of great significance as far as European Union is concerned. Numerous Member States of European Union considered the withdrawal of International Security Assistance Force from Afghanistan at the end of 2017 significant, even if the country still had to face several thousands of soldiers from USA and NATO. In 2013 the high-level talks between European Union and Central Asia regarding safety sector began. All of those countries, excluding Turkmenistan, hold European Union delegations. What is more, European Union intends to establish a delegation in Mongolia (Garces de los Fayos, 2018, pp. 1-3).

The countries of the Central Asia are provided financial resources from the European Instrument for Development: EUR 1028 million for the period of time from 2014 to 2020 (increase in relation to the period of time from 2007 to 2013 when the financial resources amounted to EUR 750 million) that will be used for funding both bilateral assistance and regional programmes (EUR 30 million). The aid measures are provided mostly for education, regional safety, sustainable management of natural resources as well as socio-economic development. Recently, Kazakhstan had stopped benefiting from the bilateral assistance in terms of this instrument, however, it still has an access to the regional programmes. In the future, a similar situation may take place in Turkmenistan. European Instrument for Democracy and Human Rights functions in each country, except Uzbekistan and Turkmenistan where the civil society organizations are too small, weakly organized as well as fully controlled (Garces de los Fayos, 2018, pp. 1-3).

European Union is observed to takes three types of actions as far as Central Asia is concerned. Those include adopted positions (resolutions), interparliamentary cooperation and last but not least, election observation and promotion of democracy.

The adopted positions (resolutions) (Garces de los Fayos, 2018, pp. 1-3):

- The Parliament supported the European Union strategy regarding Central Asia, however in its resolution of 13 April 2016, it urged its better orientation.

- In terms of Kazakhstan, the Parliament underlined the significance of both reaching an agreement regarding reinforced agreement of partnership and cooperation and taking actions aimed at human rights abuses. It also welcomed the acceptance of this country to WTO in 2015. The Parliament also claimed that it will use the rule "more for more" with regard to both political and socio-economic reforms.

- In 2010, as a gesture of its solidarity with Kyrgyzstan, the Parliament adopted a resolution due to violent riots in the south part of this country. In 2015, it addressed the concerns over establishing a register of non-governmental organizations and a draft of rules in the context of the so-called LGTBI propaganda in Kyrgyzstan.

- As far as Tajikistan is concerned, in 2009 the Parliament allowed the agreement regarding partnership and cooperation, however it called this country for improving the situation concerning human rights, corruption, health and education.

- The Parliament is consistently concerned about the poor situation concerning human rights in Turkmenistan.

- On December 2016 it approved the protocol regarding textile products concluded between European Union and Uzbekistan, however, it condemned the forced labor and called for monitoring the human rights. 
- The Parliament's statements regarding Mongolia are mostly focused on economic issues, however, those also refer to the development of the country and its humanitarian needs related to extremely difficult climatic conditions. On April 2016 Mongolia was a host of the $9^{\text {th }}$ Asia-Europe Parliamentary Meeting.

Each year the Parliamentary Cooperation Committees take part in the meetings with the Central Asia countries. The members of the Committees review the implementation of the agreements regarding partnership and cooperation and are focused on the issues of human rights, political violence, economic cooperation and development cooperation as well as election processes cooperation. Although Parliamentary Cooperation Committees concerning cooperation with Mongolia and Turkmenistan have not been established yet (due to the fact that the agreements regarding partnership and cooperation with those countries are not applied yet), the Interparliamentary Meetings are taking place (Garces de los Fayos, 2018, pp. 1-3).

Due to the differences in terms of the level of political development and significantly high differentiation of the level of democratic progress in Central Asia, the Parliament has not begun to regularly monitor the elections in the mentioned region:

- The delegations of the Organization for Security and Cooperation in Europe/Office for Democratic Institutions and Human Rights (OSCE/ODIHR) as well as the European Parliament monitored the parliamentary elections in 2015 in both Tajikistan and Kirgizstan, as a result of which the situation in the first country was considered as negative, whereas in the second country - positive.

- Kazakhstan occasionally invited the Parliament in order to monitor the elections. OSCE/ODHIR each time noticed serious irregularities.

- The delegation of European Parliament monitored the presidential elections in Mongolia in the end of June and in the beginning of July 2017 and concluded that in this country a solid democracy is being established.

- The Parliament has never been invited to the elections neither in Uzbekistan, nor in Turkmenistan.

The next part of the paper is focused on the genuine cooperation between the countries of European Union and Central Asia.

\section{Genuine components of the cooperation between European Union and Central Asia}

The Common Foreign and Security Policy (CFSP) is considered a base of shaping the European Union's external policy. Its institutional framework were specified in the Maastricht Treaty of 1992. The initial assumption regarding the development of unitary foreign policy of the Community was based on aiming to gradual consolidation of policies under political unions. The origins of CFSP date back to 1970, when WE Council of Ministers adopted so-called Devignon report on the establishment and the functioning mechanism of European Political Cooperation (Zięba, 2007, p. 10-25). During next more than 40 years, the European Union did not managed to develop a more efficient mechanism as far as international scene is concerned, despite numer- 
ous subsequent modifications of Community policies (in Single European Act, inter alia (Wiaderny-Bidzińska, 1999, pp. 164-165).

The weak capacity of European Union to "speak with one voice" on the international scene can be confirmed with the matter of the Balkans conflict, Kosovo issue or the attitude of European Union towards the Arabian Spring which is closer to contemporaneity. Lack of a homogenous, multidimensional foreign policy results into the predominance of shaping bilateral relationships of the Member States of European Union with those outside the European Union. As a consequence of the poor foreign policy of the European Union, one may also notice lack of relationship with significant regional organizations of Central Asia, such as Shanghai Cooperation Organization or Eurasian Economic Community. The actions of European Union in Central Asia are subordinated to a specific strategy elaborated for this region. Nevertheless, its direct implementation is targeted at particular countries, excluding regional organizations that integrate those countries.

Taking the political and economic processes which take place in Central Asia, a region believed as one of the pivotal areas, from which begins one of the streams of world geopolitics into consideration, European Union can be noted to be rather a prompter than an actor. Undoubtedly, one of the reasons of any engagement of European Union in Central Asia is connected with the presence of China and Russia - with those the countries of European Union have strong economic ties - with China due to the trade relations, with Russia - due to energy dependency.

Generally, the role of European Union in Central Asia is reduced to engaging into the implementation of peace processes and stabilization of the situation within the region. What is more, it does not take place directly, but by encouraging to take such actions and supporting the initiative regarding improvement of safety. Therefore, for obvious reasons, the strongest countries of this region, including Russia and China have the crucial meaning for European Union. Russia is considered as the main political force as well as the engine of shaping the regional safety arrangement (those initiatives include for instance Shanghai Cooperation Organization or Collective Security Treaty Organization), what results in striving for achieving the continuous improvement of relationship with Moscow with regard to the situation in Asia by European Union.

Kremlin may be observed to approach the cooperation with Brussels in terms of security establishment in Asia in a cautious and distanced way due to the fact that it has its own, not fully disclosed vision of stable Central Asia, including the role of Russia. It should be underlined that the role which does not necessarily fit into Brussel's notions what used to be a source of the downturn in the European Union - Russia relation in the past (Laurelle, 2011). Due to the fact that China unwillingly engages into political turmoil within the region, by ceding the actions regarding regional safety to Russia and by supporting the initiatives issued by Moscow, Russia automatically becomes the only crucial partner concerning this scope for European Union in Central Asia. At the same time, without the engagement of Russia and building cooperation with Moscow, Brussel is not able to actively work in favor of widely understood regional safety (Laurelle, 2011).

The main directions of the European Union strategy in Central Asia, with a focus on five republics: Kazakhstan, Uzbekistan, Tajikistan, Kyrgyzstan and Turkmenistan, are connected with providing a political stability, sustainable economic development 
as well as initiating and supporting democratization processes. The strategy of European Union actions towards Central Asia is built on three main pillars (Emerson et al., 2010, pp. 8-11):

1) Supporting the actions aiming at providing energy security of the republics, in terms of raw materials as well as the access to water resources. Furthermore, supporting actions directed into the elimination of the threats connected with political instability of Afghanistan.

2) Special treatment of Kazakhstan as an "exemplary" republic, which had implemented both market-oriented and democratic rules to the greatest extent as its own "Path to Europe." Furthermore, supporting the process of shaping positive relations with Uzbekistan which is the biggest regional competitor of Kazakhstan.

3) Focusing on broadening the regional context of Central Asia with regard to directing into relations with East Europe, Southern Asia as well as Russia and China. It means that Central Asia is no longer perceived in the context of shaping the cooperation mostly within five republics for the benefit of perceiving the region in a broader, Eurasian context, as a center in which the interests of China, Russia, Europe, Southern Asia and United States meet.

The mentioned five republics is often referred to as "difficult European Union customers" due to political instability, economic and social issues as well as conflicts on the religious and national backgrounds. Brussels notices the dependence relying on achieving political stability in its actions which is strictly connected with achieving political stability with reference to providing an economic development of republics. The tools used in order to implement European Union strategy towards the countries of this region include Technical Assistance for the Commonwealth of Independent States (TACIS) and Development Cooperation Instrument (DCI) which aims at supporting the democratic and premarket transformations (Boostra et al., 2008, pp. 13-15).

The range of the European Union engagement can be observed due to the funds for supporting Central Asia in terms of assistance programme for the period 2007 to 2013, which are totally estimated to EUR 356 million and the total budget of the implementation of European Union strategy within this region amounted to EUR 719 million (Emerson et al., 2010, pp. 8-11).

The fact that the Brussel is focused on the actions connected with using the financial assistance under the above tools is often the reason to criticize the European Union for too narrow and too technical perceiving issues of Central Asia. The main areas of the criticism of the European Union politics towards Central Asia and the reasons of the poor effects of undertaken actions include the following (Shao, 2008, pp. 13-15):

1) Lack of aspirations of European Union regarding supporting the shaping process of regional cohesion across divides, and mostly across the individual aspirations of republics to build cultural and political identity being the source of tensions and conflicts between neighbors.

2) Lack of differentiation (individualization) of the approach to particular republics, including the difference in terms of their actual needs.

3) An erroneous belief of European Union regarding the abilities of the republics to cooperate in order to provide a regional development and establish one block in international forum, similar to the Baltic states. 
4) Not taking the role of Uzbekistan into consideration, as the only country bordering all of the remaining republics and being in conflict with them as a main obstacle to shaping regional cooperation.

As far as shaping forthcoming relationship of European Union with Central Asia republics is concerned, a crucial role was played by instant recognition of their independence and quick submission of a proposal to establish bilateral relationship basing on the agreements concerning partnership and cooperation (Partnership and Cooperation Agreements - PCAs). The process of ratification of agreements with particular republics proves both the tedious character of building the position of European Union in Central Asia and the accuracy of referring to five republics as mentioned "five difficult clients."

Due to the fact that the process of adjustment of republics in terms of fulfilling the conditions necessary to sign PCAs is long and demanding, it requires the support of European Union. Therefore, Technical Aid to the Commonwealth of Independent States (TACIS) programme is considered as an invaluable aid for republics. In 1999 the agreements with Kazakhstan, Kyrgyzstan and Uzbekistan were ratified. In case of the last listed republic, in 2005 due to violation of the human rights, the European Union decided to partially suspend the provisions of the agreement up to 2008. In 2004, the agreement with Tajikistan was signed, however, due to unstable internal situation, its ratification took place only in 2009. As far as Turkmenistan is concerned, the agreement was signed in 1998, however, due to a pro-Russian attitude of the president Nyyzaov, France and Great Britain refused its ratification. After taking power by the president Berdimuhamedow in 2007 and after the amendment of internal and foreign policy, the ratification was expected to take place in 2010, however despite the passage of years the procedure remains on-going (Emerson et al., 2010, p. 58).

Shaping the economic relations with the countries of Central Asia by European Union is largely subordinated to European Union policy of promoting democratic forms of government and respecting the rights of the independent market as well as human rights. Furthermore, it is subordinated to the anti-discrimination regarding racial and gender equality and last but not least, widely understood religious and national tolerance.

As a consequence of the fact that the models of providing governance in Asian postSoviet republics are closer to authoritarianism than to democracy it may be observed that the European Union engagement in terms of economy slows down. The assumptions of the European Union strategy towards Central Asia were formulated in 2007, during German presidency. The first document outlining the framework of cooperation was Regional Strategy Papers for Assistance to Central Asia (RSP) for the period 2007 to 2013. The second, more detailed elaboration provided by the Commision was Central Asia Indicative Programme (IP) for the period 2007 to 2010. Several months later a comprehensive EU Strategy for Central Asia was adopted (Boonstra, 2012).

Despite the Brussel's growing interest in Central Asia in terms of the order of priority of regional foreign policies, this area remains on the fringe of European Union actions. It mostly results from focusing the attention on positive cooperation and providing stability in the border regions of European Union, therefore it includes the Mediterranean basin (with particular focus on Maghreb), Eastern Europe, as well as 
Caucasus. Indeed, the actions of European Union towards Central Asia are divided into four main areas (Boonstra, 2012):

1) Assistance in terms of achieving security and regional stability;

2) Access to natural raw materials (mostly energy materials);

3) Promoting democratic values and human rights;

4) Assistance in order to comply with international development criterion.

The main area of Central Asia economic interest by European Union include reserves of natural resources and a possibility of using them in order to develop the energy stability of Member States of European Union. European Union investments concerning this area would raise living standards, however, on the other hand - would allow the republics to become a part of the international global economy and become more dependent on Russia. However, the attention should be paid to the fact that cooperation in that regard would be mainly focused on the republics with energetic raw materials, that include Kazakhstan and Tajikistan. The remaining republic could benefit at most from additional incomes due to the transit of raw materials to Europe.

Kazakhstan is the largest trading partner of the European Union. In 2003 the total amount of commercial turnover amounted to EUR 5.8 million. Due to relatively low level of technical advancement in relation to European Union countries, up to $80 \%$ of the European Union import is constituted by the low-processed energy products. As far as Kazakhstan is concerned, it imports machinery and devices as well as products of the chemical industry from European Union (Shao, 2008, pp. 13-15).

During the next years of $21^{\text {st }}$ century, the trade turnover between European Union and Central Asia was increasing and in 2010 it amounted to the total level of EUR 22,229.1 million. The share of particular republics in trade changed. The absolute leader of the ranking was Kazakhstan in which $32.4 \%$ of total trade turnover of European Union in this region was due. Turkmenistan with the share of $16.1 \%$, mostly due to the export of raw materials, was ranked at the second location. As far as the third place is concerned, it went to Uzbekistan with the turnover at the level of $15.6 \%$. Nevertheless, it should be mentioned that a characteristic element of trade in this particular case is continuing imbalance between the share in imports $(20.5 \%)$ and exports $(8.2 \%)$. A similar disproportion can be seen in Tajikistan which ranks as the fourth due to $7.9 \%$ of turnover. Its share in imports amounted to $9.8 \%$, whereas in terms of exports - it was only $3.7 \%$. As a consequence of this relation between the share in imports and exports, local economies are proven to be poorly technically advanced. Kyrgyzstan, as a fifth of republics with the share of $3.8 \%$ plays a margin role in terms of European Union trade with Central Asia (Boonstra, 2012).

From the European Union's interests point of view, Kazakhstan remains the most significant country of Central Asia, mostly due to its considerable economic potential, based upon being rich in natural resources. It is also caused by relatively advanced processes of democratization of socio-political life as well as the marketization of the economy. What is more, the location and large area make this republic a "strategic corridor" merging Asia with Europe. It should be also underlined that the pro-Russian direction of president Nazarbayev's policy does not interrupt the process of competing with Russia for the supplies of energy raw materials to Europe that currently constitute almost $80 \%$ of Kazakh export to European Union (Dave, 2008, pp. 43-44). 
The economic development of Kazakhstan is not accompanied with the process of democratization of social and political life in a way that would be considered satisfactory by the European Union. On the contrary, the actions of president Nazarbayev suggest striving for strengthening autocratic characteristics of entrusted power. The repeated examples of violating the human rights and vicious repression against political opposition (especially with Islamic one) had almost resulted in depriving Astana of chairmanship in Organization For Security And Co-operation in Europe (OSCE), which was finally possessed in 2010 .

During the German presidency in European Union the role of Kazakhstan in terms of the development of social, economic and political processes taking place in the entire Central Asia was considered crucial, especially in the context of shaping regional stability and safety. As a consequence, European Union decided that both promoting democratic reforms and the transparency of political procedures and economic processes will become its priority in terms of actions towards Astana in order to make Kazakhstan be considered as a stable and responsible partner, an excellent example of positive and successful changes within the region. One of the most significant reasons of that particular interest of European Union in Kazakhstan is not only the richness in terms of natural resources, but also economic success which Kazakhstan owes to deposits of oil and gas. It is confirmed by the following numbers: the estimated GPD of Kazakhstan in 2000 amounted to USD 18 billion, USD 80 billion in 2007 and it is forecasted that until 2015 those amounts may double (Dave, 2008, pp. 43-44).

The main objective of Brussel is not only tightening economic ties with Kazakhstan, but also demonstrating that the dynamic economic development benefits from democratic reforms as well as so-called principles of good governance. This would make Kazakhstan a shining example of the synergy of economic and democratic development within the described region and therefore, contribute to making the implementation of European Union strategy in Central Asia easier (Dave, 2008, pp. 43-44).

\section{Conclusion}

The past achievements of European Union in terms of the implementation of the current strategy towards Central Asia indicate a significant engagement of Brussel as far as the development of the region is concerned. The priorities of European Union engagement are still as follows: the problem of human rights abuses, violating legal standards, investment in youth and education, supporting economic development, trade and investment, development and strengthening of energy and shipping bonds, fight against local threats (terrorism, crime), intercultural dialogue and last but not least, solving the problems connected with natural environment protection as well as water resources.

Despite a systematic tightening of cooperation between Brussel and republics, a lack of clear identification of genuine, long-term European Union interests within the region is still observable. The problem of European Union actions in Central Asia (and not only there) is a strong fragmentation of structures as well as lack of coordination between them in terms of undertaken actions. Consequently, despite relatively 
considerable engagement in various regions of the world, European Union is criticized by other institutions as well as international donators due to low effectiveness of actions, chaos in terms of their implementation as well as duplication of the scope of undertaken initiatives.

The main areas of the ambiguity and deficit of institutional solutions as well as other groups of problems make the effectiveness of European Union actions lower. As the result, the following three necessary supervisory actions have been indicated:

1) A fundamental re-calculation whether the actions in seven crucial areas of the strategy are effective.

2) Evaluation of the probability that the available raw materials are actually sufficient for the implementation of strategic objectives.

3) Strengthening of the limited capacity of European Union to affect the provision of security in Central Asia.

A strong sidetracking of European Union actions regarding a variety of areas implemented by numerous institutions in five different republics indicates that the improvement of information exchange, gaining greater control and coordination as well as limiting the thematic scope of undertaken initiatives are necessary.

The effectiveness of European Union actions taken towards Central Asia in the mentioned areas is also highly dependent on the scope of cooperation with Russia and China as main actors of the political scene in the described region.

Despite the fact that interests between the Russian Federation and European Union differ in terms of energy, the European Union cannot ignore the position of Russia in Central Asia, especially with respect to the declared need of providing a stability in this region. In particular, as mentioned before, Russia plays a crucial role in terms of shaping security in Central Asia and that role will become even bigger after the withdrawal of the American army from Afghanistan which is still unstable. During the implementation of its strategy toward the region, the European Union has to respect Russian strategic objectives which include maintaining the position of security guarantor and the implementation of Russian energy interests. It should be also underlined that Kremlin still believes in the success of their cooperative initiatives, protecting political and economic influence in republics under EurAsEC and CSTO.

The growth of European Union engagement in Central Asia is, from the Moscow point of view, drives the competition for the influences in the region regardless the fact that the crucial European Union initiatives do not aim at strengthening the position of Brussel, but at providing economic stability, security as well as democratization of political and social life in the republics. The current position of Moscow in the region is definitely stronger than Brussel's and the tools of its reinforcement by Kremlin are observably more effective than by European Union. The objective of European Union is not the aspiration for weakening Russian influences, but using them in order to implement a politically neutral European Union strategy. However, the distrust of Russian government practically eliminates the possibility of the cooperation between Moscow and Brussel regarding issues sensitive to Kremlin, such as the fight against terrorism and organized crime (weapons, drugs). The situation will not change if Russia would not stop perceiving European Union as a competitor in terms of using natural resources (oil and gas) what also results from accusing the Commission of endeavoring to creat- 
ing an energy monopoly by Gazprom in Central and East Europe as well as in postsoviet Central Asia.

\section{Bibliography}

Bello O. (2010), The EU - Africa Partnership: At A Strategic Crossroads, "FRIDE Policy Brief," May.

Boonstra J., Halle J. (2010), EU Assistance to Central Asia: Back to the Drawing Board?, "EUCAM Papers," January, no. 8.

Boonstra J., Halle J. (2011), EU Development Ministers Discuss Approach to Central Asia, "EUCAM Commentary," July, no. 16.

Boonstra J., Laurelle M., Peyrouse S. (2012), Security and Development Approaches to Central Asia. The EU Compared to China and Russia, "EUCAM Working Paper," May, no. 11.

Dani A. H., Hasson V. M. (1992), History of Civilization of Central Asia. Volume I. The Dawn of Civilization: Earliest times to 700 B.C., Unesco Publishing, Paris.

Dave B. (2008), The EU and Kazakhstan: Is the Pursuit of Energy and Security Cooperation Compatible with the Promotion of Human Rights and Democratic Reforms, in: Engaging Central Asia. The European Union's New Strategy in the Heart of Eurasia, ed. N. J. Melvin, Brussels.

Emerson M., Boostra J., Hasanova N., Laurelle M., Peyrouse S. (2010), Into Eurasia. Monitoring The EU's Central Asia Strategy, CEPS-FRIDE, Brussels-Madrid.

Garces de los Fayos F. (2018), Azja Centralna, Dokumenty informacyjne o Unii Europejskiej, Bruksela.

Laurelle M. (2011), Why the EU Needs to Engage Russia on Asian Security, "FRIDE Policy Brief," June, no. 82.

Mydel R., Groch J. (2000), Popularna Encyklopedia Powszechna, Azja T. I, Fogra, Kraków.

Olędzki J. A. (2014), Zaangażowanie Unii Europejskiej w rozwój gospodarczy i spoleczny Azji Centrlanej. Stan i Perspektywy, "Studia Europejskie," vol. 2.

Shao Y. (2008), The EU's Central Asia Policy and Its Implications for China, "DIE Discussion Paper," no. 9.

Wiaderny-Bidzińska K. (1999), Polityczna integracja Europy Zachodniej, "Acta Scientifica Academiae Ostroviensis," vol. 4.

Zięba R. (2007), Wspólna Polityka Zagraniczna i Bezpieczeństwa Unii Europejskiej, Wyd. Akademickie i Profesjonalne, Warszawa.

\section{Summary}

This article analyzes the scope of cooperation at the institutional and bilateral level of the European Union and Central Asia. Despite the systematic tightening of cooperation between Brussels and the republics of the former USSR, there is still a lack of unambiguous definition of real long-term interests of the European Union in the region. The fundamental problem of cooperation development is a strong fragmentation of EU activities in five different republics of Central Asia. Therefore, there is a need to improve the exchange of information, increase control and coordination, as well as limit the thematic scope of undertaken initiatives. There are potential diversification opportunities for energy sources that exist in the Central Asia region.

Key words: European Union, Central Asia, Cooperation, Institution, Bilateral 


\section{Współpraca na poziomie instytucjonalnym i bilateralnym Unii Europejskiej oraz Azji Środkowej/Centralnej}

\section{Streszczenie}

W niniejszym artykule analizie poddano zakres współpracy na poziomie instytucjonalnym i bilateralnym Unii Europejskiej i Azji Centralnej. Mimo systematycznego zacieśniania współpracy Brukseli z republikami byłego ZSRR, nadal brakuje jednoznacznego określenia rzeczywistych, długookresowych interesów Unii Europejskiej w regionie. Zasadniczym problemem rozwoju współpracy jest silne rozdrobnienie działań unijnych w pięciu różnych republikach Azji Centralnej. W związku z tym wskazuje się konieczność poprawy wymiany informacji, zwiększenia kontroli i koordynacji, a także ograniczenia zakresu tematycznego podejmowanych inicjatyw. Istnieją potencjalne możliwości dywersyfikacji źródeł surowców energetycznych, które występują w regionie Azji Centralnej.

Słowa kluczowe: Unia Europejska, Azja Środkowa, współpraca-kooperacja, instytucja, bilateralny-dwustronny 
